ISSN1027-5495. Functional Materials, 24, No.3 (2017), p. 501-508

doi:https://doi.org/10.15407/fm24.03.501

(C) 2017 - STC "Institute for Single Crystals"

\title{
Study on cutting performance and tool wear of micro-textured tool for milling Ti6Al4V
}

\author{
Shen Xiang-yu, Guo Xu-hong, Deng Da-song, Lu Li-li, Chen Ya-dong \\ College of Mechanical and Electric Engineering, Soochow \\ University, Suzhou, Jiangsu 215006, China
}

Received February 11, 2017

\begin{abstract}
The research found that the surface texture applied to the cutting tool could improve the frictional states of tool-chip and tool-workpiece effectively. In order to study the technology of surface texture how to effect the cutting performance of the integral end milling cutter for cutting titanium alloy (Ti6AlV). The longitudinal grooves, lateral grooves and pits were prepared by laser processing technique on the rake face of milling tool made of YG6X, which was to explore the cutting performance of non-texture tools and texture tools under the condition of dry and lubrication. As the results, compared with the non-textured tools, the longitudinal micro-groove and micro-pit could effectively reduce the milling force, increase the chip curl and improve the anti-sticking properties of the tool, thereby the oxidation wear, adhesive wear of the rake face and the abrasion wear of the flank face were alleviated as well. The experimental results demonstrated that the milling force of the tool with longitudinal micro-groove was reduced by $62 \%$ and the width of wear on rake face was reduced by $68 \%$, the wear width on the flank face of the micro-pits tool was decreased by $42.6 \%$.The direction of micro-groove on the tool's rake face had a great influence on the anti-sticking properties, and the tools with longitudinal micro-grooves had the best anti-sticking property. The fine medium played a major role in improving the friction between the tool-chip friction pairs.
\end{abstract}

Keywords: End milling cutter, micro-texture, milling force, chip morphology, tool wear

Исследовано влияние поверхностной текстуры торцевой фррезы из титанового сплава (Ti6AlV) на ее изностойкость. Продольные канавки, боковые канавки и углубления были получены методом лазерной обработки передней поверхности фррезерного инструмента. Исследовалась производительность резки нетекстурированных инструментов и инструментов с текстурой в условиях сухого резания и смазки. Показано, что по сравнению с инструментами, не подвергнутых текстурированию, продольные микроканавки и микроуглубления эфффективно уменьшают износ инструмента, увеличивают скручивание стружки и улучшают антипригарные свойства инструмента. Экспериментальные результаты показали, что трение инструмента с продольной микроканавкой было уменьшено на $62 \%$, a ширина износа на передней поверхности была уменьшена на $68 \%$, ширина износа на боковой поверхности инструмента с микроуглублениями уменьшилась на 42,6\%. Направление микроканавки на передней поверхности инструмента оказывает большое влияние на антипригарные свойства, а инструменты с продольными микроканавками имели лучшие противозадирочные свойства.

Дослідження ефективності різання і зносу інструменту для мікроізмельченний Ti6Al4V. SHEN Xiang-yu, GUO Xu-hong, DENG Da-song, LU Li-li, CHEN Ya-dong

Досліджувався вплив поверхневої текстури торцевої фррези з титанового сплаву (Ti6AlV) на її стійкість. Поздовжні канавки, бічні канавки і поглиблення були отримані методом лазерної обробки передньої поверхні фррезерного інструменту. Досліджувалася продуктивність різання нетекстурованих інструментів і інструментів 3 текстурою в умовах сухого різання і мастила. Показано, що в порівнянні з інструментами, не підданих текстуруванню, поздовжні мікроканавки та мікроуглубленія ефективно зменшують 
знос інструменту, збільшують скручування стружки і покращують антипригарні властивості інструменту. Експериментальні результати показали, що тертя інструменту 3 поздовжньою мікроканавками було зменшено на $62 \%$, а ширина зносу на передній поверхні була зменшена на $68 \%$, ширина зносу на бічній поверхні інструменту 3 мікроуглубленія зменшилася на 42,6\%. Напрямок мікроканавки на передній поверхні інструменту дуже впливае на антипригарні властивості, а інструменти з поздовжніми мікроканавками мали кращі протівозадірочние властивості.

\section{Introduction}

The traditional mechanical design and tribology theory generally believe that smooth surface helps to reduce friction and wear, so the machining technology had been developing to the direction of the high precision and low surface roughness. On the other hand, the application of surface texture also has a long history. The engine cylinder liner crossed the texture pattern has been a successful example since the 1940s [1]. With the deep research on surface texture technology, domestic and foreign scholars had applied surface texture technology to the field of cutting tools. The related research showed that the tool with smoother rake and flank face was not more anti-friction, but the surface with texture always had better wear resistance. The study of the texture morphology mainly included convex hull, pit, groove and scaly. Over the past decade, the development of micro-fabrication technology had made it possible to control the shape precisely. The scale and interface property of texture could be optimized as well.

At present, the study shows that the high quality of the cutting tool with the surface texture can achieve good anti-friction, anti-adhesion and improve wear resistance, etc., thereby it can also improe the cutting performance of the tool. Lei S [6] and others found that the texture tool reduced the cutting force and tool-chip contact length. T. Enomoto [7] and N. Kawasegia [8] also found that the trench texture tool could reduce the tool-chip contact length, effectively reduce the cutting force and improve the wear resistance of the tool as well. T. Sugihara [9] and others demonstrated that the trench-type texture could improve the adhesion of the tool's surface, and that the micro-texture size would affect the wear resistance of the tool. Then N. Davi [10] and others proved that the tool with texture had stronger the anti-stick property. In addition, the study found that, the cutting performance of the tool varied with the angle between the texture and the cutting edge and the density of the texture distribution although it had the same specifications. W.L.Chang [11] and others had found that the cutting force and tool's wear was minimum when the angle between the texture and the cutting edge was $90^{\circ}$. W. Silva [12] and others found that the cutting tool had the best cutting performance when the texture was parallel to the main cutting edge. T. Ling [13] and others found that the drill with the texture had better chip breaking and higher durability. Similarly, Yang Chao [14] and others found that the texture's diameter, depth, area occupancy rate and other parameters affected the cutting performance of the tool.

The existing studies have shown that a reasonable surface microstructure can improve the tool's surface friction characteristics and cutting performance. However, the micro-texture technology applied to the cutting tool is still in its infancy, and its application to rotating tool is less studied. The main reason is that the study about the mechanism of tool's anti-friction and anti-wear is not enough, which needs scholars to do more experimental research. The main idea of this paper is that the micro-texture technique can improve the lubrication of the contact friction pairs. We would process different types of texture on the tool's rake face by the laser technology, which is based on the surface micro-texture technology and cutting fluid lubrication technology. The purpose of this paper is to explore the cutting performances of the tool with different textures and wear conditions for cutting titanium alloy Ti6Al4V material, which will make a certain foundation for further study of surface texture cutters.

\section{Texture tool fabrication and test scheme}

\subsection{The design of tool's surface}

The cutting tool used for the experiments is uncoated integral end mill which is made cemented carbide (YG6X), and the hardness of the tool surface is HRA91. The main parameters were showed in Table 1 . The longitudinal micro-grooves(parallel to the main cutting edge), lateral micro-grooves (perpendicular to the main cutting edge)and micro-pits were prepared on the rake face of milling tool by laser marking machine, which was respectively called TA,TB and TC for short. The non-texture tool was simplified as TW. The processed area and types of texture were showed in Fig. 1. 


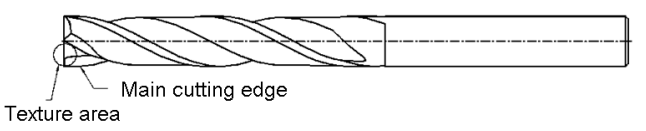

a) Schematic diagram of milling tool

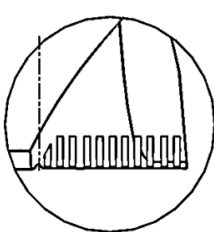

b) TA type texture

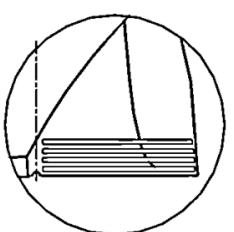

c) TB type texture

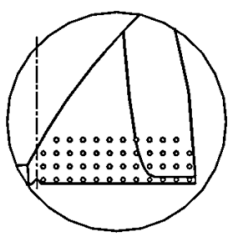

d) TC type texture
Fig.1 Processed area and types of texture

\subsection{Tool texturing}

The laser marking machine was THFLMS10 which the main parameters were showed in Table 2. Through experimental verification, the marking effect was the best when the reasonable parameters of the laser were chosen $(V=100 \mathrm{~mm} / \mathrm{s}, f=25 \mathrm{KHz}, P=16 \mathrm{~W}$ and processed twice). In addition, the groove-texture was suitable for the back filling method, and the pit-texture was suitable for non-filling method. After the preparation of the texture, W5 metallographic sandpapers were used to polish the machined surface texture and the ultrasonic cleaner was used to clean away the impurity for $15 \mathrm{~min}$. Then, the texture was characterized by super-depth microscope (VHX-1000) and the results were showed in Fig.2. The width and spacing of the grooves were about $100 \mu \mathrm{m}$, the pits' diameter and spacing were about $100 \mu \mathrm{m}$. All of the textures' depth was about $35 \mu \mathrm{m}$, and the parameters of the texture met expected design.

\section{Test conditions and methods}

Cutting experiments are conducted on titanium alloys Ti6Al4V using a machining center called HAAS VF-1. For the cutting parameters, the cutting velocity $V_{\mathrm{c}}$ is $120 \mathrm{~m} / \mathrm{min}$, the feed rate $f$ is $0.06 \mathrm{~mm} / \mathrm{r}$, the cutting width ae is $0.5 \mathrm{~mm}$, the cutting depth ap is $1 \mathrm{~mm}$, the milling mode is down milling, lubrication conditions are divided into dry and emulsion lubrication. A dynamometer (Kistler 9257B) was set under

Table 1 Geometric parameters of the tool

\begin{tabular}{|c|c|c|c|c|c|}
\hline $\begin{array}{c}\text { Number of } \\
\text { teeth }\end{array}$ & $\begin{array}{c}\text { Diameter } \\
/ \mathrm{mm}\end{array}$ & $\begin{array}{c}\text { Blade } \\
\text { length } / \mathrm{mm}\end{array}$ & $\begin{array}{c}\text { Helix } \\
\text { angle } /\left(^{\circ}\right)\end{array}$ & $\begin{array}{c}\text { Rake } \\
\text { angle/ } /\left(^{\circ}\right)\end{array}$ & $\begin{array}{c}\text { Relief } \\
\text { angle/ } /\left(^{\circ}\right)\end{array}$ \\
\hline
\end{tabular}

Table 2 The main parameters of laser marking machine

\begin{tabular}{|c|c|c|c|c|c|}
\hline Wavelength/nm & $\begin{array}{c}\text { Laser } \\
\text { power/W }\end{array}$ & Frequency/KHz & $\begin{array}{c}\text { Pulse } \\
\text { width/us }\end{array}$ & $\begin{array}{l}\text { Minimum spot } \\
\text { diameter/pm }\end{array}$ & Precision/um \\
\hline
\end{tabular}

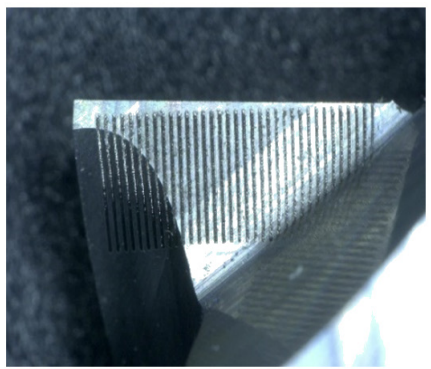

a) TA textured milling tool

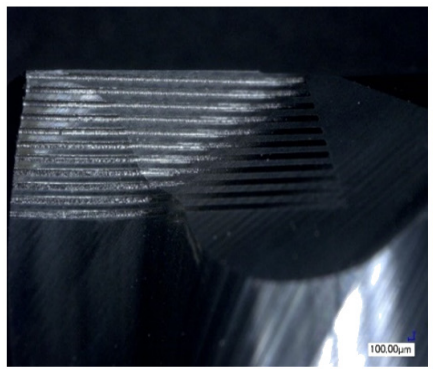

b) TB textured milling tool

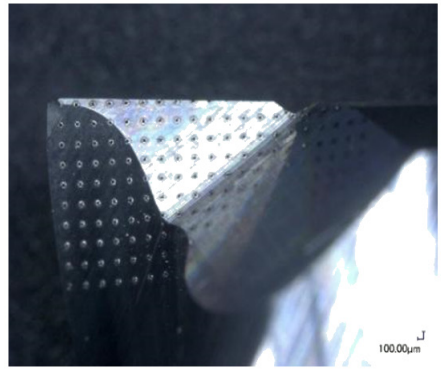

c) TC textured milling tool

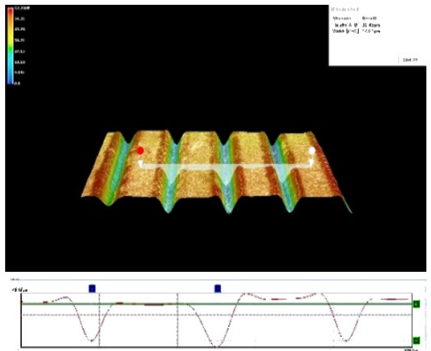

d) Groove texture

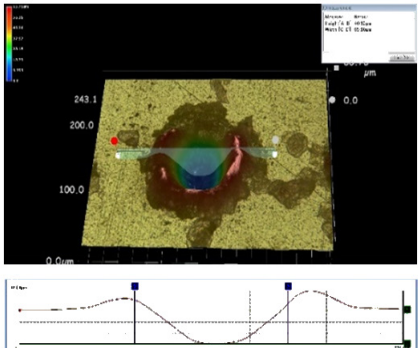

e) Pit texture

Fig.2 Morphology of textured tools and micro-texture 
the workpiece to measure three components of the cutting forces after the cutting length of $2000 \mathrm{~mm}$. Different types of tools were prepared 3 and each tool's cutting force data was taken the average as the final result. A scanning electron microscopy (SEM) and energy dispersive spectrometer (EDS) ZEISS Axio Observer were used to analyze the rake wear and the chip morphology respectively. A metallographic microscope ZEISS Axio Observer was used to measure the flank wear.

\section{Test results}

\subsection{Cutting force}

Fig. 3 was the radial force $\mathrm{Fx}$, the main cutting force $\mathrm{Fy}$, the axial force $\mathrm{Fz}$ and the resultant force $\mathrm{F}$ of the mi-cro-texture tool and non-texture tool measured under differ-ent lubrication conditions. It could be seen from the figure that the texture with different shapes had different effects on the cutting force for cutting titanium alloy under dry cutting and wet cutting conditions. The Fx, Fy and Fz of TA, TC texture tool were significantly lower than that of the non-texture tool, but the cutting forces of the TB tool were much greater. Fig. 4 (d) was the histogram about the resultant force $\mathrm{F}$ of different tools. Compared with the non-textured tool, the cutting force of TA and TC tool respectively de-creased by $62.0 \%, 38.1 \%$ and $53.9 \%$, $7.1 \%$ under dry cutting and lubrication cutting conditions, but the cutting force of TB tool increased by about 8 times. The cutting force of TA tool in dry cutting is $6.2 \%$ lower than which in wet cutting, the TC textured tool is $-1.7 \%$ (the force in dry cutting is less than that in the wet cutting).

The results showed that the cutting force of TA and TC tool decreased more than that of the non-texture tool in the dry cutting condition, and the cutting force of TA texture tool was the smallest under the two kinds of cutting conditions; The TA tool's cutting force in dry cutting condition is higher than which in wet cutting condition, but the TC tool's force in dry cutting condition was lower than which in wet cutting condition, which indicated that TC tool was suitable for cut-ting titanium alloy without cutting fluid.

\subsection{Chip morphology}

Some representative chips of different cutting tools were selected to analyze by electron microscopy (SEM), as shown in Fig. 4. It can be seen from the figure that the length of nontexture tool's chip was longer, the curl of the chip was smaller. Compared with non-texture tool's chip, the chips' morphology of TA and TC tool were similar, they were spiral, more curly and the chip's length was relatively shorter. However, for the TB tool, the chip deformed irregularly, the curl direction was uncertain, and there was the adhesion between the chips, as shown in Fig. 4 (c).

\subsection{Wear pattern and mechanism}

\subsubsection{Rake wear and mechanisms}

Fig. $5(\mathrm{a}, \mathrm{b})$ were the SEM images of the nontexture tool's rake wear. It was obviously seen that the wear occurred near the main cutting edge of the non-texture tool (shown in area of B) and a large number of adhesives were present as well(shown in areas of A and C) in figure 6 (b). There was micro-pits whose surface appearing some trench in the area of $\mathrm{B}$, which was in line with the characteristics of crescent depression wear, so it indicated that the non-texture tool's rake face occurred crescent depression wear. With the aid of the EDS composition, components in $\mathrm{A}, \mathrm{B}$ and $\mathrm{C}$ were listed in Table 3. The adhering substance on the area of A, C looked different from the appearance, and EDS showed the elements of the adhering substance were also different. These incidents suggested that the adhering substance in area of $\mathrm{A}, \mathrm{C}$ was not the same. The area of A mainly contained $\mathrm{O}, \mathrm{W}$, Co elements, of which $\mathrm{W}$ and Co were the main constituent elements of the cemented carbide tool. According to literature [15], YG6X carbide tool during the process of cutting Ti6Al4V could occur oxidation reaction, and the oxides were $\mathrm{WO} 3, \mathrm{TiO} 2$ and $\mathrm{Co} 3 \mathrm{O} 4$. It can be deduced that the black adhering substance in area of A was WO3 and Co3O4. In addition, there was no $\mathrm{Ti}, \mathrm{Al}, \mathrm{V}$ elements that was the main constituent elements of Ti6Al4V in area of A, which indicated that the area of A did not contain material bonding. Areas of B, $\mathrm{C}$ contained $\mathrm{O}$ elements and $\mathrm{Ti}, \mathrm{Al}, \mathrm{V}$ elements that was the elements in the cutting materials proved that these areas had both oxides and material bonding. In summary, the non-texture tool could reacted oxidative wear and adhesive wear when dry cutting.

Compared with non-texture tool, the adhering substance near the main cutting edge of TA and TC tool reduced obviously, as shown in Fig.5(c)-(e). Especially, TA tool's surface had no material bonding basically. But the phenomenon of material bonding on TB tool's surface was still very serious. These Indicated that TA and TC tool for cutting titanium alloy had antisticking properties, while TB tool did not. It can be seen from Table 3 that the proportion of $\mathrm{O}$ element in area of D, E and F decreased, which inferred that the degree of oxidization near the cutting edge of the texture tool became low, so oxidation wear on these texture tools' rake face was slowed. Fig. 6 shown the wear width on the 

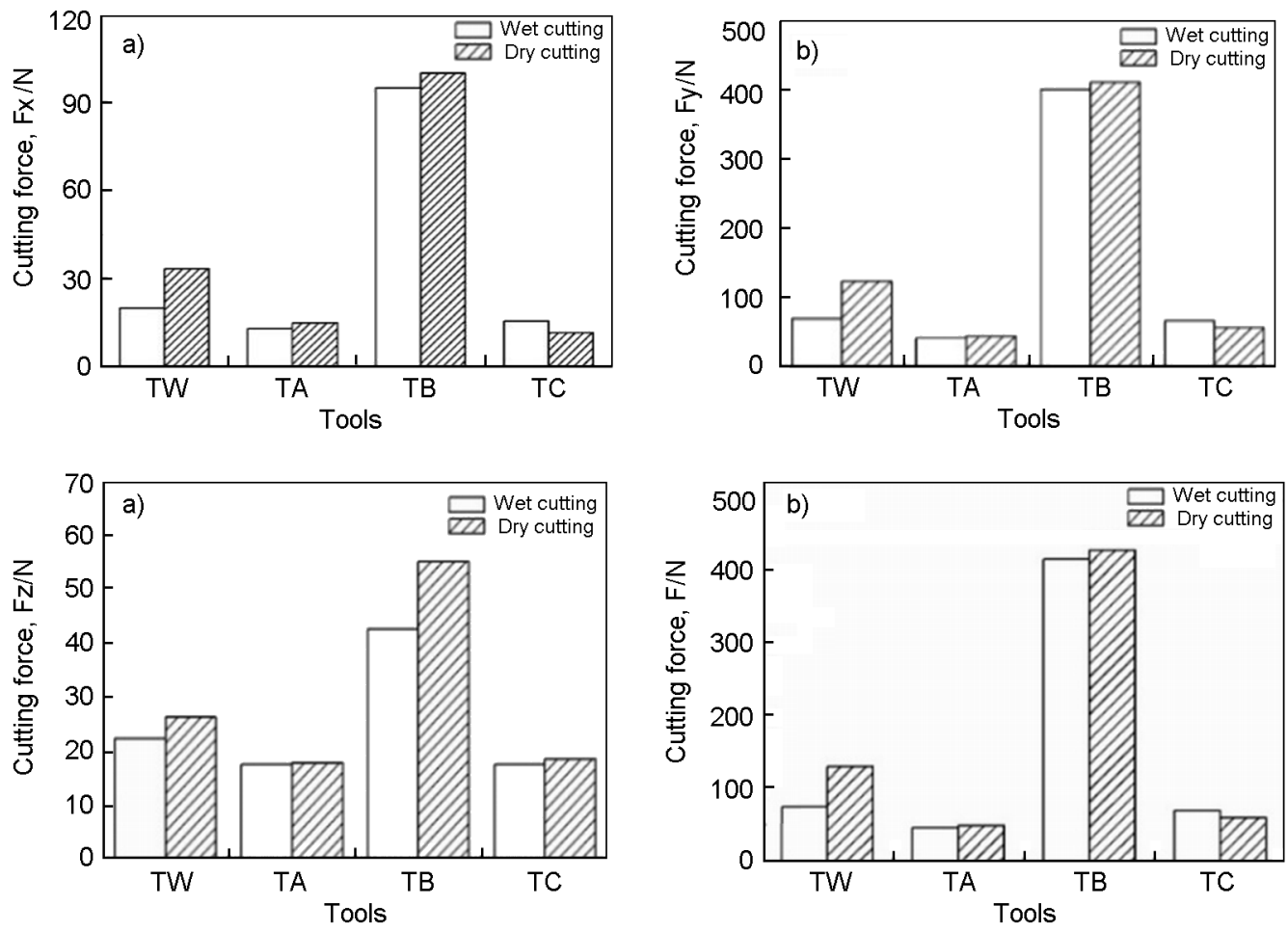

Fig.3 Cutting force of different tools

different tool's rake face. Compared with the non-texture tool, the wear width of TB tool's rake face was the largest, that of TA and TC tools decreased by $68 \%$ and $37.5 \%$ respectively, In summary, the TA and TC texture could slow the oxidative wear and adhesive wear on the tool' rake face.

4.3.2 Flank wear and mechanism

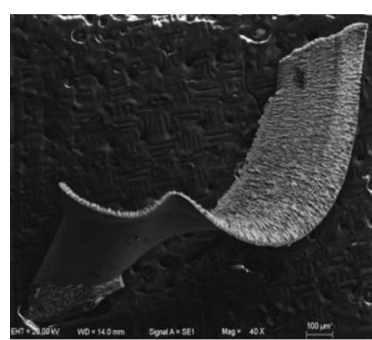

a)

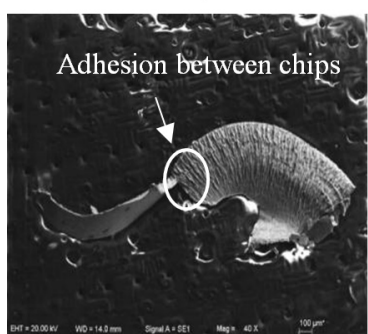

c)

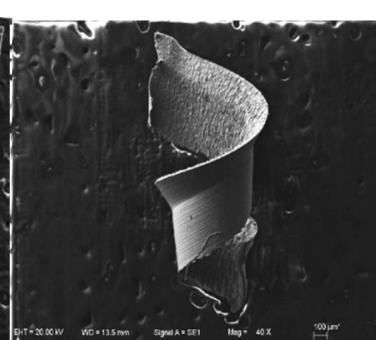

b)

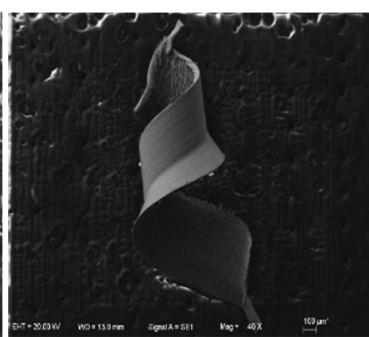

d)
Fig.4 SEM micrographs of different tools' chip. a) Non-textured tool's chip.100x; b) TA-textured tool's chip.100x; c) TB-textured tool's chip.100x; d) TC-textured tool's chip.100x
Fig. 7 was the wear patterns of different tools' flank face under a metallurgical microscope. It could be seen from the figure that a large number of groove marks occurred near the main cutting edge of the non-texture tool and TC tool. These marks conformed to the characteristics of the abrasive wear, which manifested that the non-texture tool and TC tool occurred the abrasive wear. The wear width of the non-texture tool and TC tool was $418 \mu \mathrm{m}, 240 \mu \mathrm{m}$ respectively. Compared with non -texture tool, the TC tool's wear width was reduced by $42.6 \%$, and the TA tool's wear was not obvious. However, there was lots of adhesion on the flank face of the TB tool because of the material's sintering. So, TA, TC texture could slow down the abrasive wear on the tools' flank face.

\section{Discussion and analysis}

The cutting result showed that the TA and $\mathrm{TC}$ tool could reduce the milling force, increase the chip curl and improve the anti-sticking properties of the tool, thereby the oxidation wear, adhesive wear of the rake face and the abrasion wear of the flank face were alleviated as well, which was compared with the non-texture tool. So, the cutting performance of the TA and TC tool was better than the non-texture tool. However, the TB tool not only increased the cutting force, but also had serious bonding 


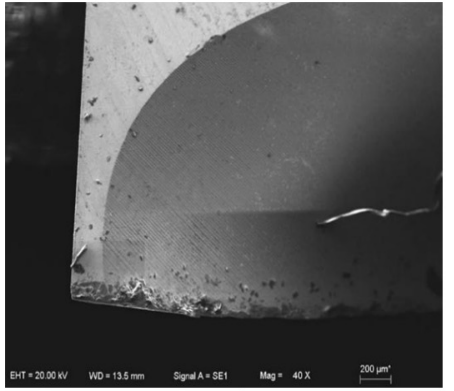

a)

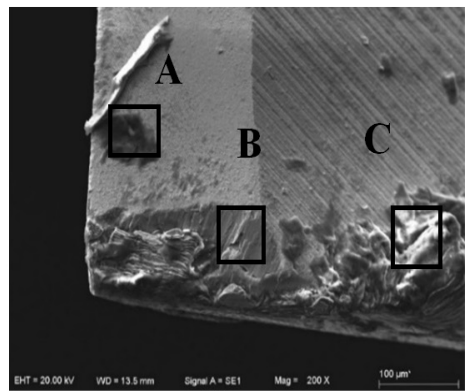

b)

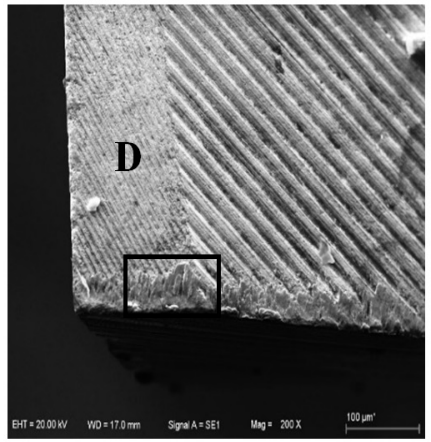

c)

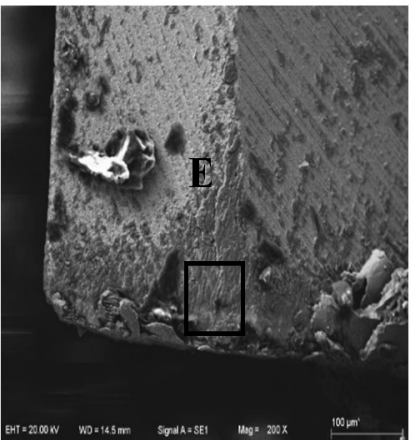

d)

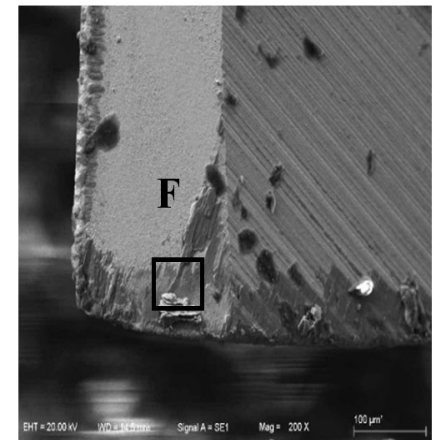

e)

Fig.5 SEM micrographs of different tools' rake face. a) Non-textured tool.40x; b) Non-textured tool.100x,; c) TA-textured tool.100x; d) TB-textured tool.100x; e) TC-textured tool.100x.

and wear, and even discovered the phenomenon of chip sintering during the cutting process.

For the TA tool, the chip's flow direction was perpendicular to the texture during the cutting process, which was shown in Fig.7 (a). The textures placed on the rake face helped to add a lot of cutting edges which could make a part

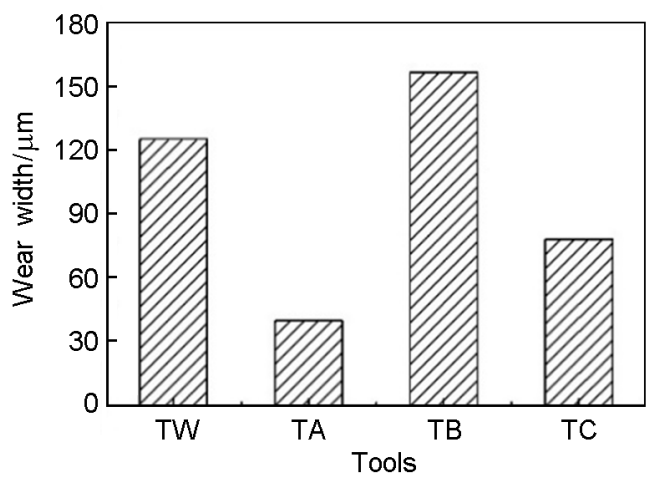

Fig.6. Wear width of tools on rake face

of the chip break into fine chip due to "secondary cutting" of the cutting edge when the chips flowed through the texture friction pairs. As shown in Fig.7 (c), the fine chips with combination of titanium alloy hard particles could be reserved in the groove and the contact interval of the chip and the rake face. These fine medium played the same role with the rollers of the bearing at the moment of cutting, which could improve the friction of the tool-chip fric- tion pairs and decrease milling force; In addition, the chip parallel to the fiber direction was higher in plasticity and tenacity than that vertical to fiber direction due to the directivity of the chip's mechanical property[17] .So the TA tool whose textures were vertical to the fiber direction of the chip had the better chip breaking capacity, and their anti-sticking property was the best. But the performance of the TB tool was opposite to that of the TA tool because of the direction of TB tool's textures, as shown in Fig.3. Because the micro-pit had the same isotropy, and the forces around the pits were uniform [18], so the TC tool showed good chip breaking ability and anti-sticking effect.

For the TB tool, Fig.7 (c) showed that the effective cutting edge's length acting on the inner surface of the chip was much smaller than that of the TA, TC tool, which led to reduce the relative number of fine chips. Furthermore, the fine medium could be filled in the texture's trench with the chip flow instead of forming an effective lubricating layer between the friction pairs. In addition, the texture placed on the tool's rake face had increased the roughness of tool's surface and the lubrication condition of frictional pairs became deteriorated without the lubricating layer. So, the cutting force of the TB tool increased sharply. During the test, it was found that the cutting force of the TC tool under the dry cutting was smaller than that of wet cutting. First of all, the notch wear 


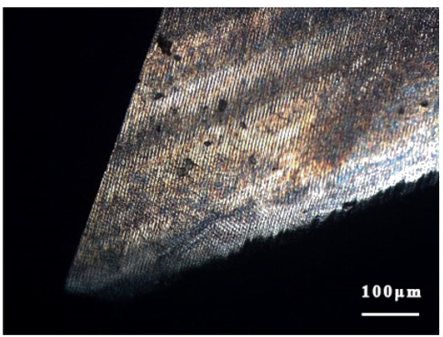

a)

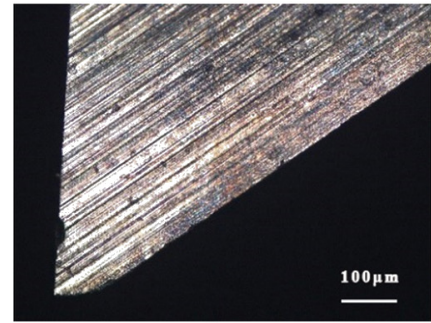

d)

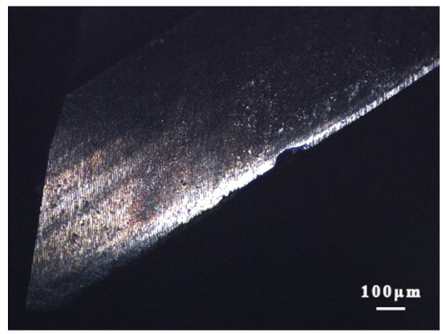

b)

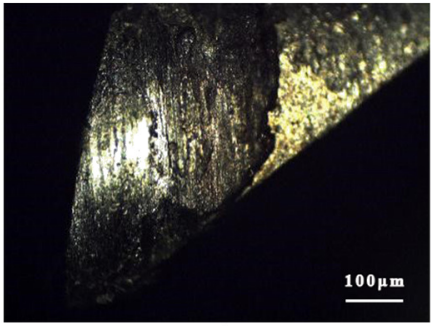

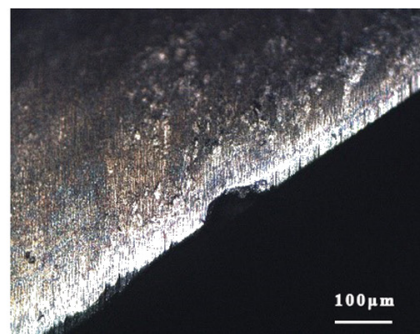

c)

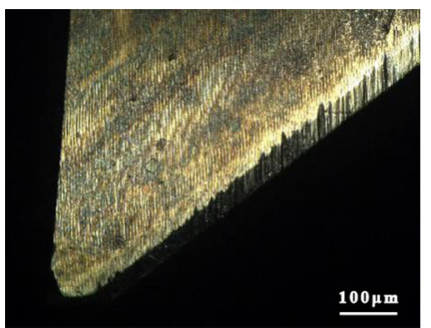

f)

Fig.7. The wear patterns of different tools' flank face under a metallurgical microscope. a) TW-textured tool.100x; TW-textured tool.50x; c) micro-chipping of TW.100x; D) TA-textured tool.100x; e) TB-textured tool.100x; f) TC-textured tool.100x

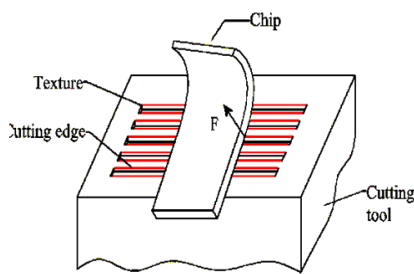

a)

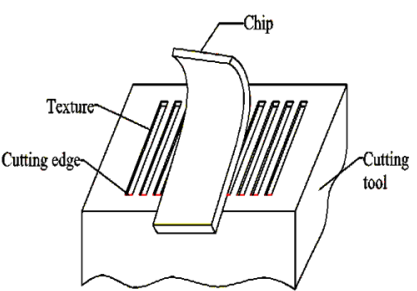

b)

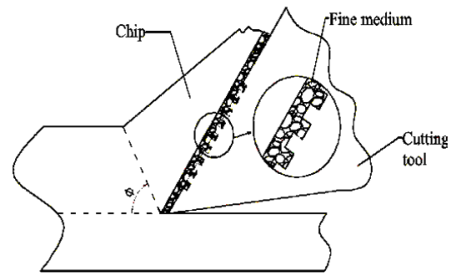

c)

Fig. 8. Schematic diagram of tool-chip contact during the cutting process of textured tools. a) The cutting diagram of TA; b) The cutting diagram of TB; c) Lubrication diagram of the textured tool

was the main wear form on the flank face of the tool mainly due to the repeated grind of the abrasive particles during the high-speed cutting process for the titanium alloy [19]. Fig. 8(f) showed that there was lots of grooves near the main cutting edge, which indicated that the TC tool increases the possibility of hard particles' formation. Secondly the micro-pit with circular cross-section had lower ability to stay in fine medium than TA-groove, therefore the fine medium in the micro-pits were rushed to the tool-workpiece contact area by the impact force of cutting fluid and the centrifugal force. That was why the notch wear of the TC tool got aggravated and the cutting force became slightly larger in the wet cutting. However, the TA-texture was better in the storage of fine medium, so the possibility of notch wear became lower. Under the action of the auxiliary lubrication from the cutting fluid, the cutting force got lower in wet cutting than that in dry cutting. In summary, the improvement of the lubrication condition in the contact friction was mainly due to the effect of the fine medium stored in the tool-chip contact area.

\section{Conclusion}

By comparing the cutting test of different texture tool and non-texture tool, the conclusions were as followed.

Compared with the traditional end mill, the appropriate surface texture could improve the cutting performance of the tool, mainly to reduce the milling force of the tool, increase the chip curl, improve the adhesion condition of the tool's rake and flank face, slow down oxidation wear, adhesive wear of the rake face and abrasive wear of the flank face. Especially the tool with the longitudinal groove had the best cutting properties.

The direction of the micro-groove placed on the end mill affected the tool's anti-sticking performance. The micro-groove parallel to the main cutting edge could effectively improve the tool adhesion phenomenon. The micro-groove perpendicular to the main cutting edge could aggravate the tool's adhesion, even it led to the phenomenon of chip sintering during the cutting process.

In the cutting process of the texture tool, the fine medium played a major role in improving 
the friction condition of the tool-chip friction pairs, in which the cross-sectional shape of the texture affected the ability of the texture tool to stay in the fine medium. The capacity of the micro-pit to stay in the fine medium was poor.

\section{Acknowledgments}

The project is supported by Funding of Jiangsu Innovation Program for Graduate Education (ZY32003615) and the Achievements Transformation Project of Jiangsu Province(BA2014004)

\section{References}

1. E.Wilis, Wear, 109(1-4): 351, 1986,.

2. E.Gualtieri, A.Borghi, L. Calabri, et al. Tribol. Int., 42(5), 699, 2009.

3. D.Marchetto, A.Rota, L. Calabri, et al., Wear, 265 (5), 577, 2008.

4. I.H. Sung, H.S. Lee, D.E.Kim, Wear, 254 (10), 1019, 2003.

5. J.Q. Wang, X.L.Wang, J. Mech. Eng., 51(23), 84, 2015.

6. S.T.Lei, S. Devarajan, Z.H. Chang, J. Mater.Proces.Technol., 209(3), 1612, 2009.

7. T. Sugihara, T. Enomoto, Precis. Eng., 36(2), 229, 2012.
8. N. Kawasegi, H. Sugimori, H. Morimoto, et al. Precis. Eng., 33(3), 248, 2009.

9. T. Sugihara, T. Enomoto, Precis. Eng., 37, 888, 2013.

10. N. Davi, D. Anselmo, L. Milton, Appl. Surf. Sci., 282, 680, 2013.

11. W.L. Chang, J. Sun, X.H. Luo, M.R. James, M. Chirs, Wear, 271, 2433, 2011.

12. Silvaw, Suarez M, Machado A, et al. Wear, 302, 1230, 2013.

13. D. Lingtiffany, Liu Pin-zhi, Xing Shang-wu, et al. Tribol. Lett., 52, 113, 2013.

14. C. Yang, X. J. Liu, H.D. Yang, et al., Tribol., , 2(35), 228, 2015.

15. Y.S. Li, Chemical Performance match between cemented carbide tools and Ti-6AI-4V alloy [D]. Shandong:Shandong University,2010.

16. Li A H, Zhao J, Luo H B, et al. ,Tribol., 32(1), 40, 2012.

17. Fu Y H, Xiao K L, Hua X J, et al., China Surf. Eng., 26(6), 106, 2013.

18. Yu Z J, Cai Q Q, Wang X X, Xu J K, Yu H D., China Surf. Eng., 29 (6), 1, 2016.

19. Yu H O. Study on the Wear Mechanism and characteristics of carbide tool in high-speed milling with titanium alloy [D].Shenyang: Shenyang Ligong University, 2015. 